\title{
Avaliação das condições de operação de equipamentos hidrossanitários em edificações públicas
}

\author{
Evaluation of operating conditions of plumbing fixtures in \\ public buildings
}

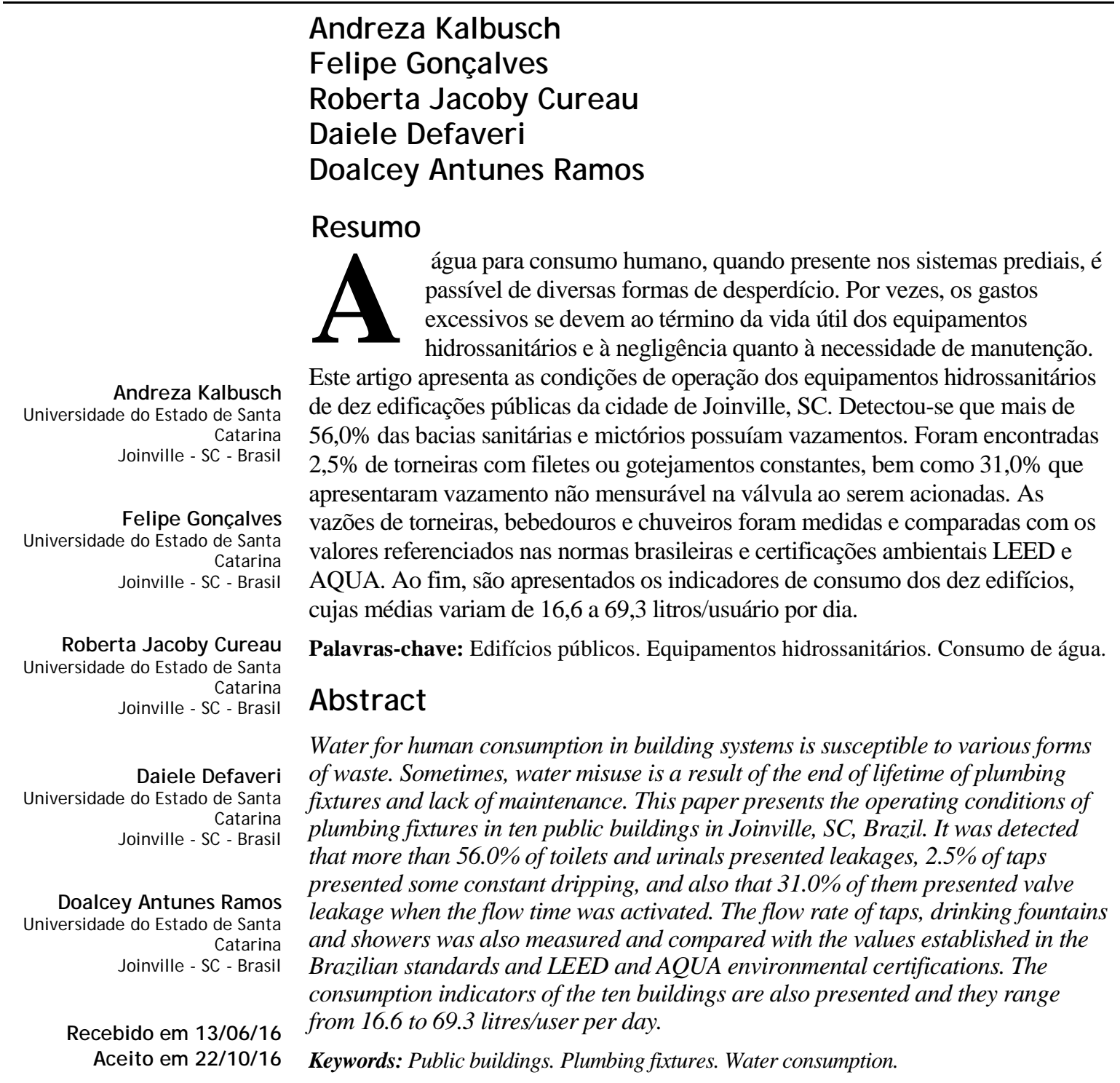




\section{Introdução}

Edifícios públicos normalmente apresentam índices elevados de desperdício de água quando comparados a espaços administrativos privados. Essa diferença é dada por uma associação de aspectos: a infraestrutura é muitas vezes inferior; incentivos para manutenção dos equipamentos hidrossanitários praticamente inexistem; os usuários não são diretamente responsáveis pelo pagamento das taxas de água, como afirma Nunes (2000); e apesar de consistirem em locais de elevado fluxo de pessoas, eles detêm alta burocracia.

Diante desses fatos, para se alcançar o uso racional da água, torna-se importante o estudo das condições de operação apresentadas pelos equipamentos hidrossanitários, assim como o emprego de dispositivos economizadores. Marinho (2007) menciona que a substituição de componentes convencionais por economizadores tem por objetivo reduzir o consumo independentemente da atitude do usuário ou de sua posição quanto à mudança de comportamento. Assim sendo, as ações tecnológicas constituem uma forma eficiente para aperfeiçoar o consumo, como demonstram os resultados obtidos por Demanboro et al. (2015).

No caso de bacias sanitárias, Proença e Ghisi (2010) mencionam a importância de ações corretivas objetivando o uso racional de água, dado o percentual de consumo de água desses equipamentos em edifícios de escritório. Ilha, Gonçalves e Oliveira Júnior (2002) afirmam que bacias sanitárias detêm alto potencial não só para consumir água, como também para perdê-la por meio de vazamentos. Do mesmo modo, é um equipamento que possui grande capacidade para economia.

No entanto, mesmo equipamentos instalados com o objetivo de economizar água, como por exemplo torneiras de funcionamento hidromecânico que substituem as de acionamento manual, também podem apresentar problemas. De acordo com Gonçalves et al. (2000), torneiras de funcionamento hidromecânico podem apresentar falhas como tempo de fechamento fora dos limites especificados, vazamento na haste ou até disparos involuntários, tendo como possíveis causas desde o desgaste do pistão até a deterioração do retentor. Daí a importância da manutenção periódica desses equipamentos hidrossanitários.
Conforme afirma Oliveira (2002), desperdício de água ocorre quando, disponível em um sistema hidráulico, ela se perde antes de realizar sua atividade final, ou quando é de fato utilizada para tal atividade, no entanto em quantidades excessivas. Se há desperdícios mesmo na presença de intervenções tecnológicas específicas que visam economizar água, quando os equipamentos hidrossanitários carecem de manutenção o gasto excessivo é ainda maior. Como os sistemas prediais assumem um papel muito importante no consumo e na economia de água, já que aproximadamente $90 \%$ da água tratada nas cidades destina-se aos setores residencial, comercial e público, como afirmam Gonçalves et al. (2005), entende-se o grau de abrangência e importância deste estudo.

É proposto neste artigo expor os valores obtidos de vazão, vazamentos e defeitos presentes em torneiras, bacias sanitárias, mictórios, bebedouros e chuveiros, bem como o indicador de consumo e as condições de operação e conservação encontradas durante as medições realizadas em dez edifícios públicos de Joinville, SC. Os dados analisados foram comparados com valores de referência normatizados pela Associação Brasileira de Normas Técnicas (ABNT) e recomendados pelas certificações Leadership in Energy and Environmental Design (LEED) e Alta Qualidade Ambiental - Haute Qualité Environnementale (AQUA-HQE).

\section{Método}

A pesquisa foi realizada por meio de uma investigação teórica e de um estudo em campo, usado para a auditoria de dados dos dez edifícios. Analisando os equipamentos hidrossanitários instalados nos dez edifícios em um quadro geral, tem-se que do total de aparelhos estudados: $47,8 \%$ são torneiras; 34,7\% bacias sanitárias; 10,1\% mictórios; 6,0\% bebedouros; e 1,4\% são chuveiros, conforme apresenta a Figura 1.

Realizou-se o levantamento do consumo de água ao longo de um ano, obtido por meio das faturas de água de cada edificação. Pelo fato de serem analisados espaços administrativos públicos, excluem-se do período histórico estabelecido os feriados e finais de semana, sendo contabilizados apenas os dias úteis de cada mês. Também foram determinados o número de funcionários e a respectiva carga horária de trabalho. 


\section{Figura 1 - Porcentagem de equipamentos hidrossanitários analisados nos Edifícios I ao X}

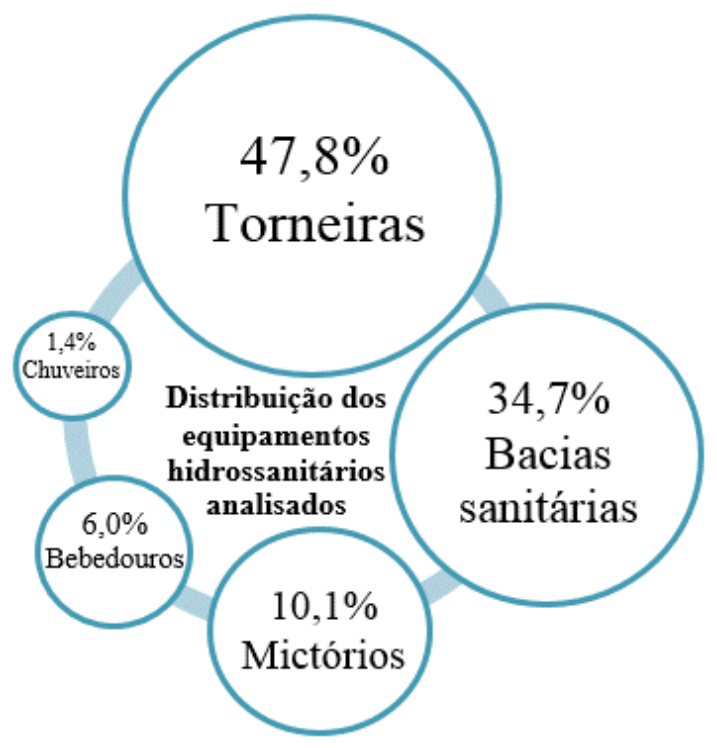

Com essas informações torna-se possível calcular o indicador de consumo (IC), que é a relação entre o volume de água consumido em um dado período e o número de agentes consumidores desse mesmo período, conforme Oliveira e Gonçalves (1999).

O indicador de consumo é apresentado na Equação 1 a seguir.

$\mathrm{IC}=\frac{\mathrm{Cm}}{\mathrm{NAxDm}} 1000$

Onde:

IC: indicador de consumo (litros/usuário/dia);

$\mathrm{Cm}$ : consumo mensal faturado $\left(\mathrm{m}^{3}\right)$;

NA: número de agentes consumidores (funcionários); e

Dm: quantidade de dias úteis no mês.

Nas torneiras instaladas em cada edifício foram observados os seguintes itens para levantamento de suas condições de operação: marca do fabricante; destinação de uso; estado de conservação; tipo de jato; presença de arejadores; tipo de acionamento da torneira; presença de vazamentos e determinação da vazão de operação, medidos por meio do método gravimétrico. Além disso, em torneiras de funcionamento hidromecânico, os tempos de operação também foram averiguados e comparados com a NBR 13713 (ABNT, 2009), a qual estabelece as recomendações para aparelhos hidráulicos de acionamento mecânico e com ciclo de fechamento automático.

Para bebedouros verificou-se:

(a) tipo e função do jato;

(b) marca do fabricante; (c) estado de conservação;

(d) forma de acionamento;

(e) verificação de vazamentos; e

(f) medição da vazão de operação, também realizada pelo método gravimétrico.

Em chuveiros, presentes somente nos Edifícios III, IV e IX, analisaram-se: marca do fabricante; condições de operação; defeitos na válvula; presença de vazamentos; e determinação da vazão operante. As medições de vazão foram realizadas por meio do método gravimétrico. Avaliou-se, ainda, a vazão máxima, que foi medida com a válvula do chuveiro totalmente aberta. O valor encontrado foi então comparado com o estabelecido pela norma NBR 12483 (ABNT, 2015b) bem como pela NBR 5626 (ABNT, 1998), LEED e AQUA.

Os valores de vazão das torneiras, bebedouros e chuveiros também foram comparados com os normatizados pela NBR 5626 (ABNT, 1998), NBR 10281 (ABNT, 2015a), certificações LEED e AQUA, apresentados na Tabela 1 juntamente com os valores estabelecidos na NBR 12483 (ABNT, 2015b). A NBR 5626 (ABNT, 1998) apresenta valores de referência para comparação, que variam de acordo com o uso das torneiras. A NBR 10281 (ABNT, 2015a) estabelece os valores mínimos de vazão para os quatro tipos de torneiras. Já os valores detalhados nas certificações LEED e AQUA referem-se a valores máximos admitidos para vazão em cada ponto de consumo de água.

Os vazamentos nas torneiras, bebedouros e chuveiros foram contabilizados somente quando visíveis, na forma de filetes (pequenos fluxos constantes de água) ou de gotejamento. As perdas 
de água nas válvulas das torneiras e os pequenos vazamentos junto ao jato não foram quantificados por ser de extrema dificuldade a medição nesses casos, como ressaltam Gonçalves et al. (2005), devido à necessidade de um medidor entre o ponto de consumo e a peça de metal. Portanto, esses vazamentos, quando identificados, foram classificados apenas como defeitos.

Para o estudo das condições de operação das bacias sanitárias e mictórios foram observados:

(a) marca do fabricante;

(b) estado de conservação;

(c) forma de acionamento da descarga;

(d) marca do mecanismo de descarga;

(e) presença de defeitos na válvula; e

(f) quando da existência de vazamentos, a quantidade de filetes por peça cerâmica.

A quantificação dos vazamentos nas bacias sanitárias e mictórios tomou como base o método da caneta, normalizado pela NBR 15097-1 (ABNT, 2011). Para execução das medições, procedeu-se à descarga dos equipamentos, havendo necessidade de interditá-los por 30-40 min para que o retardo de fluxo do acionamento não fosse confundido com vazamento.

Na sequência, as paredes das bacias e mictórios foram secas e, após isso, com uma caneta hidrográfica de cor diferente do equipamento, traçou-se uma linha em forma de circunferência a aproximadamente cinco centímetros acima da linha de água, no caso das bacias, e cerca de três centímetros acima dos furos de esgotamento, para os mictórios. Após o aguardo de três minutos, os vazamentos foram detectados pelo corrimento de filetes de água pelas paredes cerâmicas do equipamento, apagando a linha anteriormente desenhada. O método da caneta é demonstrado na Figura 2, referente às medições do Edifício X.

\section{Resultados e discussões}

A seguir são apresentados os resultados discutidos sobre cada tipo de equipamento hidrossanitário separadamente, além dos indicadores de consumo de água dos dez edifícios.

\section{Diagnóstico das torneiras}

As torneiras estavam presentes em todos os edifícios visitados nesta pesquisa, mostrando-se o equipamento hidrossanitário em maior quantidade nas dez edificações. Foram totalizadas duzentas torneiras.

\section{Dados gerais das torneiras}

Como se pode observar na Figura 3, 61,5\% das torneiras receberam classificação de lavatório, 25,0\% de limpeza (para tanque; e pátio ou jardinagem) e 13,5\% de cozinha ou copa. As torneiras que detinham acionamento hidromecânico representam 36,0\% do total. Quanto à presença de arejadores, 52,5\% não detinham o acessório. Quanto à conservação, $46,5 \%$ foram qualificadas em bom estado, enquanto $53,5 \%$ foram classificadas como regulares ou ruins por meio da inspeção visual, por terem presença de manchas, limo e ferrugem, o que poderia comprometer a qualidade da água dependendo do seu tipo de uso. Os dados apresentados mostram que a maioria das torneiras se apresenta em estado regular ou ruim de conservação, o que evidencia a falta de manutenção de suas peças. Isso pode decorrer de entraves burocráticos comuns em edificações públicas e implica dificuldades para a troca desses equipamentos antigos por novos, ou mesmo para a sua simples manutenção. Notou-se que $24,5 \%$ das torneiras apresentou jato aberto ou disperso de vazão, o que dificulta a operação adequada e aumenta o risco de uso da água em quantidades acima do necessário. Quanto aos vazamentos, $2,5 \%$ apresentaram gotejamento ou filete constante e $31,0 \%$ portavam defeito de vazamento na haste quando acionadas. Dentre as torneiras de funcionamento hidromecânico, algumas apresentaram tempo de acionamento fora dos limites recomendados, variando entre 2,2 s e 74,5 s. Segundo a NBR 13713 (ABNT, 2009), o tempo de funcionamento deve ser de $4 \mathrm{~s}$ a $10 \mathrm{~s}$. Portanto, $13,0 \%$ das torneiras de funcionamento hidromecânico não atenderam à recomendação, possuindo um tempo de vazão fora desse intervalo. Um tempo de acionamento muito baixo pode ser desconfortável para o usuário, o qual não consegue fazer uso da torneira de maneira apropriada, enquanto um tempo excessivo pode significar desperdício de água. 
Tabela 1 - Valores de vazão estabelecidos pelas normas e certificações

\begin{tabular}{|c|c|c|c|c|c|c|}
\hline \multirow{3}{*}{ Vazão (L/s) } & \multicolumn{4}{|c|}{ Torneiras } & \multirow{3}{*}{ Bebedouros } & \multirow{3}{*}{ Chuveiros } \\
\hline & \multirow{2}{*}{ Lavatório } & \multirow{2}{*}{ Cozinha } & \multicolumn{2}{|c|}{ Limpeza } & & \\
\hline & & & Tanque & Jardim & & \\
\hline NBR 5626 (ABNT, 1998) & 0,15 & 0,25 & 0,25 & 0,20 & 0,10 & 0,10 \\
\hline NBR 12483 (ABNT, 2015b) & - & - & - & - & - & 0,05 \\
\hline $\begin{array}{l}\text { NBR 10281 (ABNT, 2015a) } \\
\text { (mínimo) }\end{array}$ & 0,04 & 0,04 & 0,05 & 0,05 & - & - \\
\hline LEED (máximo) & 0,14 & 0,14 & - & - & - & 0,16 \\
\hline AQUA (máximo) & 0,17 & - & - & - & - & 0,20 \\
\hline
\end{tabular}

Figura 2 - Quatro filetes em bacia sanitária no Edifício X

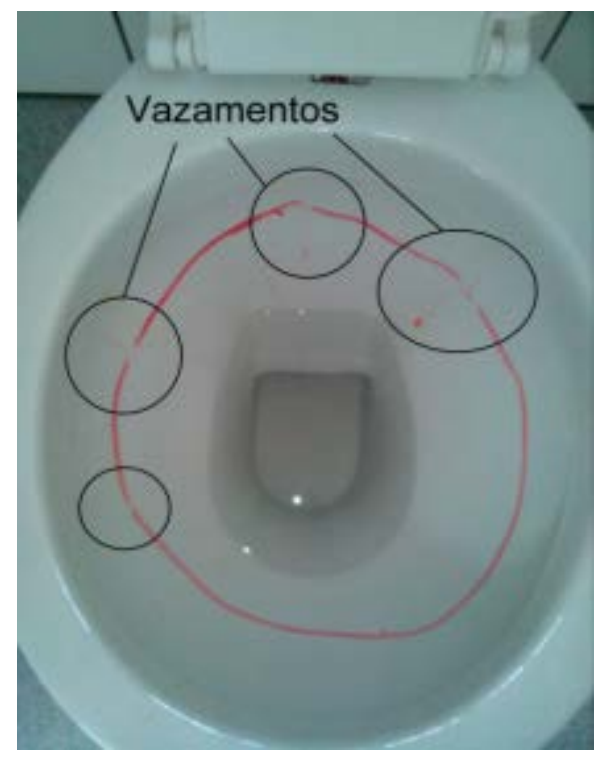

Dentre outras avarias, foram registradas sete torneiras que, apesar de funcionarem, estavam sem uso tanto pelo público quanto pelos funcionários dos edifícios. Três torneiras estavam inoperantes, ou seja, sem fluxo de água quando acionadas, e duas estavam com o arejador entupido durante a realização das medições. Também havia um ponto de consumo de lavatório que não possuía a torneira, o que impossibilitava seu uso.

Duas torneiras de funcionamento hidromecânico demonstraram ter vazão significativamente oscilante quando acionadas, operando com picos de vazão alta e baixa em um mesmo acionamento. Na Tabela 2 podem ser conferidos os cinco casos de vazamentos constantes sob a forma de filete ou gotejamento nas torneiras estudadas, bem como uma estimativa do seu desperdício de água diário.

\section{Vazão das torneiras}

As vazões das torneiras dos Edifícios $\mathrm{I}$ ao $\mathrm{X}$ também foram comparadas com os valores estabelecidos na NBR 5626 (ABNT, 1998) e nas certificações LEED e AQUA (esta última somente para lavatórios). A Figura 4 mostra a quantidade de torneiras classificadas como de cozinha ou copa operantes separadas por edifício e suas respectivas vazões. Nota-se que $81,5 \%$ das torneiras de cozinha obtiveram vazão inferior ao estabelecido pela norma brasileira e 48,1\% apresentaram vazão inferior à certificação LEED, obtendo-se a vazão média total de $0,17 \mathrm{~L} / \mathrm{s}$ para esse tipo de torneira. Apenas uma torneira apresentou vazão abaixo do mínimo estabelecido pela NBR 10281 (ABNT, 2015a). Não há referências para torneiras desse tipo na certificação AQUA para edifícios não residenciais. 
Figura 3 - Dados gerais das torneiras nos edifícios analisados

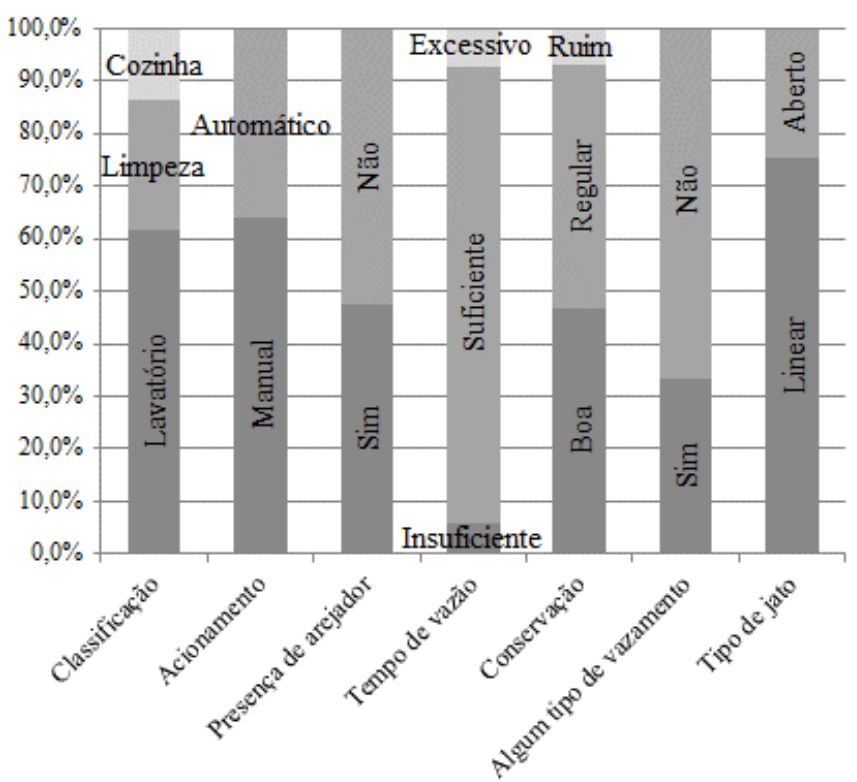

Tabela 2 - Vazamentos constantes em torneiras e seus desperdícios diários estimados nos edifícios analisados

\begin{tabular}{c|c|c}
\hline Edifício & Vazão (L/s) & Volume (L/dia) \\
\hline III & 0,0000062 & 0,5 \\
III & 0,00035 & 30,2 \\
V & 0,00084 & 72,6 \\
V & 0,00052 & 44,9 \\
VI & 0,0019 & 164,2 \\
\hline
\end{tabular}

Figura 4 - Vazão das torneiras de cozinha nos edifícios analisados

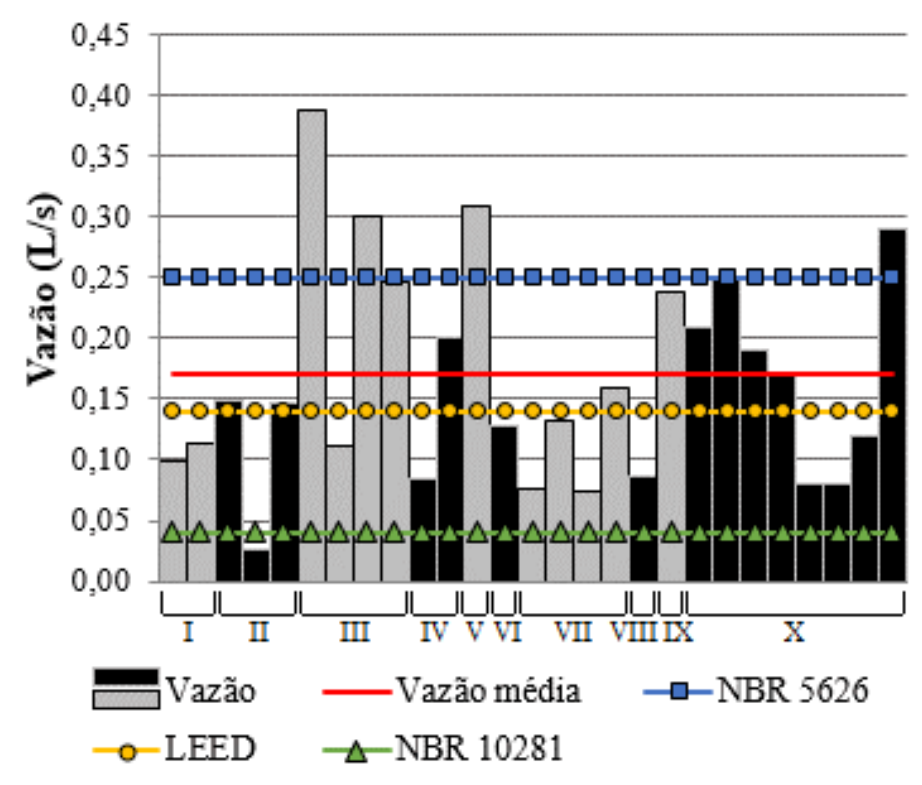

398 Kalbusch, A.; Gonçalves, F.; Cureau, R. J .; Defaveri, D.; Ramos, D. A. 
Da mesma forma, a Figura 5 revela as vazões de torneiras classificadas como de lavatório. Pode-se observar que $74,2 \%$ das vazões se mostraram abaixo do valor de referência da NBR 5626 (ABNT, 1998) e 73,4\% abaixo do valor máximo estabelecido na certificação LEED. Em relação ao selo AQUA, que estabelece a vazão máxima de $0,17 \mathrm{~L} / \mathrm{s}, 89,2 \%$ operaram abaixo deste valor. Quanto à vazão mínima de referência, 10,8\% não atenderam à NBR 10281 (ABNT, 2015a). A vazão média obtida de todas as torneiras de lavatório operantes foi de $0,10 \mathrm{~L} / \mathrm{s}$.

Pela análise da Figura 6 verifica-se que, para as torneiras de limpeza classificadas como de "tanque”, 66,7\% apresentaram vazão abaixo do valor de referência da NBR 5626 (ABNT, 1998) e somente uma não alcançou a vazão mínima da NBR 10281 (ABNT, 2015a). Não há referências do LEED ou AQUA para efeitos de comparação desse tipo de torneira. A média obtida para as vazões foi de $0,17 \mathrm{~L} / \mathrm{s}$.

Por último, a Figura 7 exibe os dados de vazão para o segundo subgrupo de torneiras com função de limpeza: as torneiras de pátio ou jardinagem. Uma torneira não obteve o desempenho mínimo de vazão indicado pela NBR 10281 (ABNT, 2015a). Novamente não existem referências do LEED ou AQUA, no entanto $69,0 \%$ se mantiveram abaixo da NBR 5626 (ABNT, 1998), com uma média total de $0,16 \mathrm{~L} / \mathrm{s}$ para as vazões encontradas.

Figura 5 - Vazão das torneiras de lavatório nos edifícios analisados

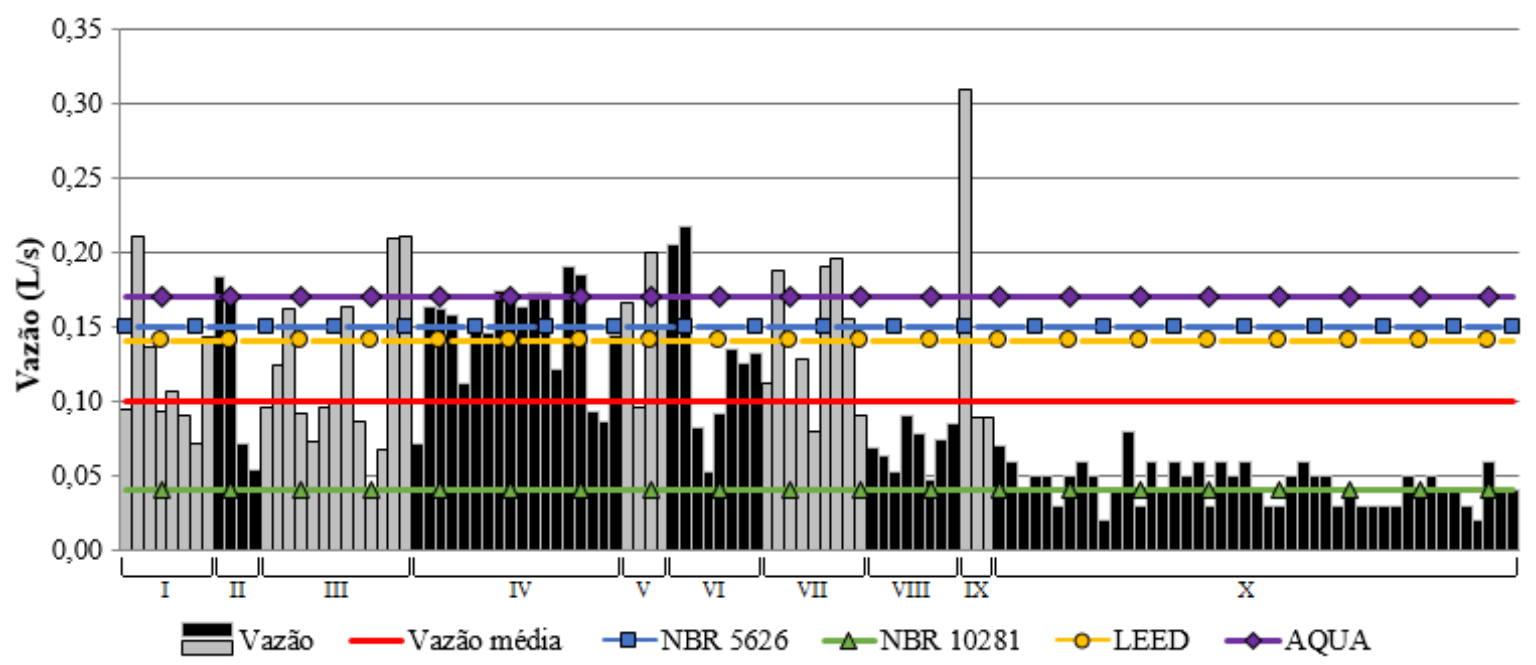

Figura 6 - Vazão das torneiras de tanque nos edifícios analisados

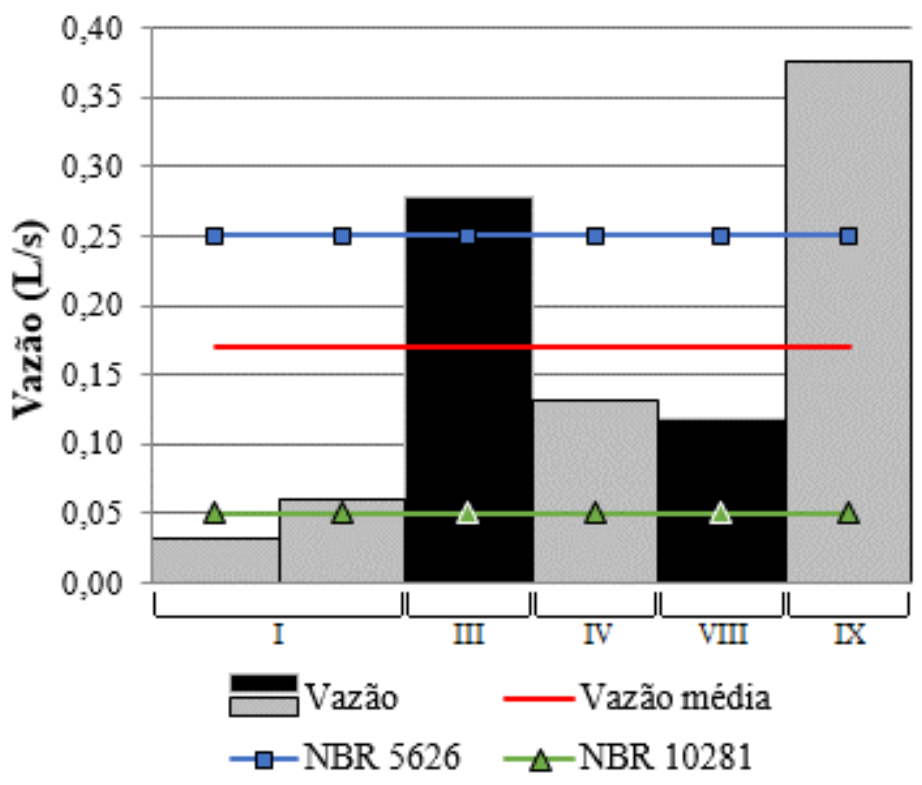


Figura 7 - Vazão das torneiras de pátio ou jardinagem nos edifícios analisados

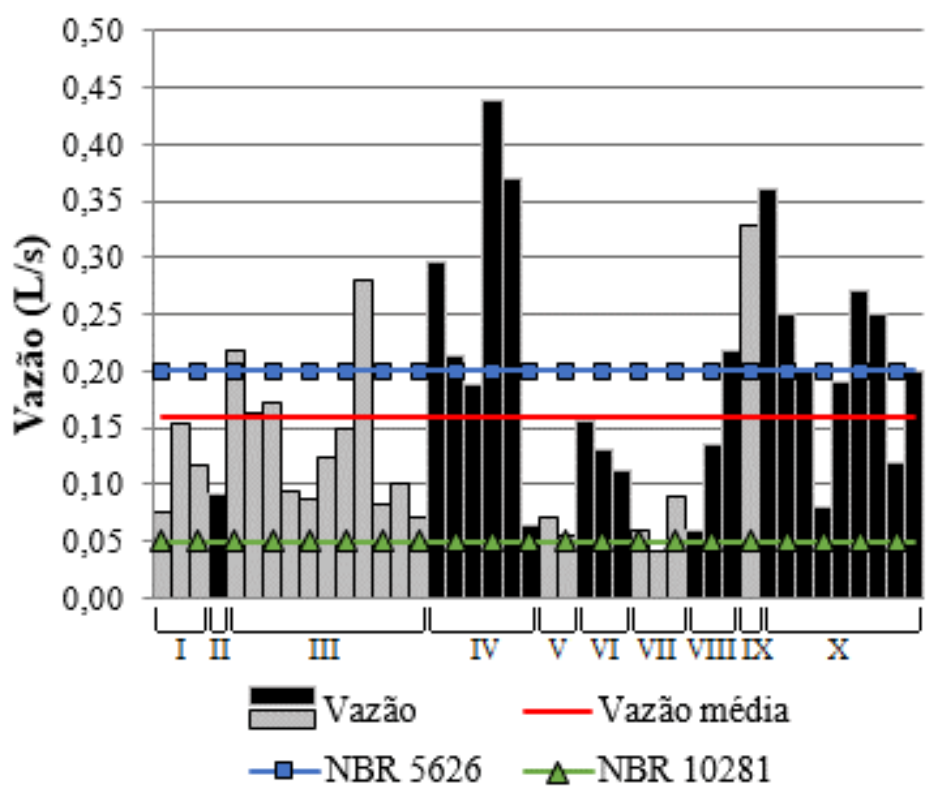

\section{Diagnóstico das bacias sanitárias}

A bacia sanitária foi o segundo equipamento mais encontrado nas visitas a campo, presente também em todos os dez edifícios públicos. Ao todo foram estudadas 145 bacias sanitárias. Seis bacias estavam interditadas pela administração dos edifícios durante as medições e, portanto, não foi possível avaliar a existência de vazamentos, somente foram avaliados seus estados de conservação, observando as condições do assento, da peça cerâmica e das válvulas de descarga.

\section{Dados gerais das bacias sanitárias}

De todas as bacias sanitárias analisadas, a Figura 8 mostra que, predominantemente, em $74,5 \%$ a limpeza se dá por acionamento de válvula de descarga. Classificaram-se $34,7 \%$ das bacias em condições regulares ou ruins, seja por assentos quebrados, ou pela falta deles; seja pelas condições precárias das válvulas de descarga, por vezes quebradas, inacabadas, manchadas e carecendo de manutenção. Apesar de 65,3\% demonstrarem bom estado conservativo, bem como uma boa condição para uso, 63,5\% apresentaram vazamento não visível sob a forma de filetes. Além disso, havia vazamento em $7,1 \%$ das válvulas de descarga quando acionadas e 13,0\% do total de válvulas estavam quebradas ou desprovidas de acabamento. Conforme a inspeção, 14,8\% das válvulas instaladas detinham duplo acionamento, ou seja, estão divididas entre acionamentos de aproximadamente 3 L e 6 L, conforme a necessidade do usuário. Em apenas 3,6\% das bacias sanitárias o assento estava quebrado ou ausente.

Também foram catalogadas duas bacias que, segundo os funcionários dos edifícios, estão sem uso e outras duas que apresentaram problema de entupimento sem estarem interditadas. Foi encontrada uma bacia que apresentava refluxo de bolhas de ar após o acionamento.

\section{Filetes das bacias sanitárias}

Pela Figura 9 nota-se que há um grande número de bacias que apresentaram filetes nos edifícios estudados. Segundo Marinho (2007), os filetes são responsáveis pelas maiores perdas de água por vazamentos em edifícios, principalmente em edificações públicas. Foi calculada uma média de 2,6 filetes por bacia sanitária.

\section{Diagnóstico dos mictórios}

Foram avaliados 42 mictórios, presentes em oito das dez edificações públicas visitadas. Quatro estavam com operação inviabilizada e por esse motivo não puderam ter suas condições de operação avaliadas.

\section{Dados gerais dos mictórios}

Observa-se pela Figura 10 que 78,6\% dos mictórios avaliados possuíam válvula de acionamento hidromecânico para descarga, com fechamento automático. Apesar de buscarem economia com a presença de válvulas de fechamento automático, mais da metade dos mictórios presentes nas edificações se encontrava 
em condições regulares. Nenhum mictório apresentou estado de conservação ruim na inspeção visual, estando 48,0\% desses equipamentos em boas condições. Registraram-se vazamentos em $27,3 \%$ das válvulas desses equipamentos quando impulsionados à descarga e, quanto às peças cerâmicas, 31,0\% exibiram filetes.

Além disso, foram identificadas outras avarias nesses equipamentos: um operou com vazão excessiva, levando a respingos nos usuários durante a descarga; outro apresentou válvula emperrada quando acionada e em dois mictórios havia vazamento na tubulação de esgoto sanitário, chegando a formar empoçamentos no chão em descargas mais prolongadas ou sucessivas, o que representa riscos higiênicos para qualquer usuário.

\section{Filetes dos mictórios}

Além de estarem presentes em menor quantidade que as bacias sanitárias, a Figura 11 mostra que os mictórios também apresentam menor quantidade de filetes por equipamento (média de 1,7 filetes por equipamento).

Figura 8 - Dados gerais das bacias sanitárias nos edifícios analisados

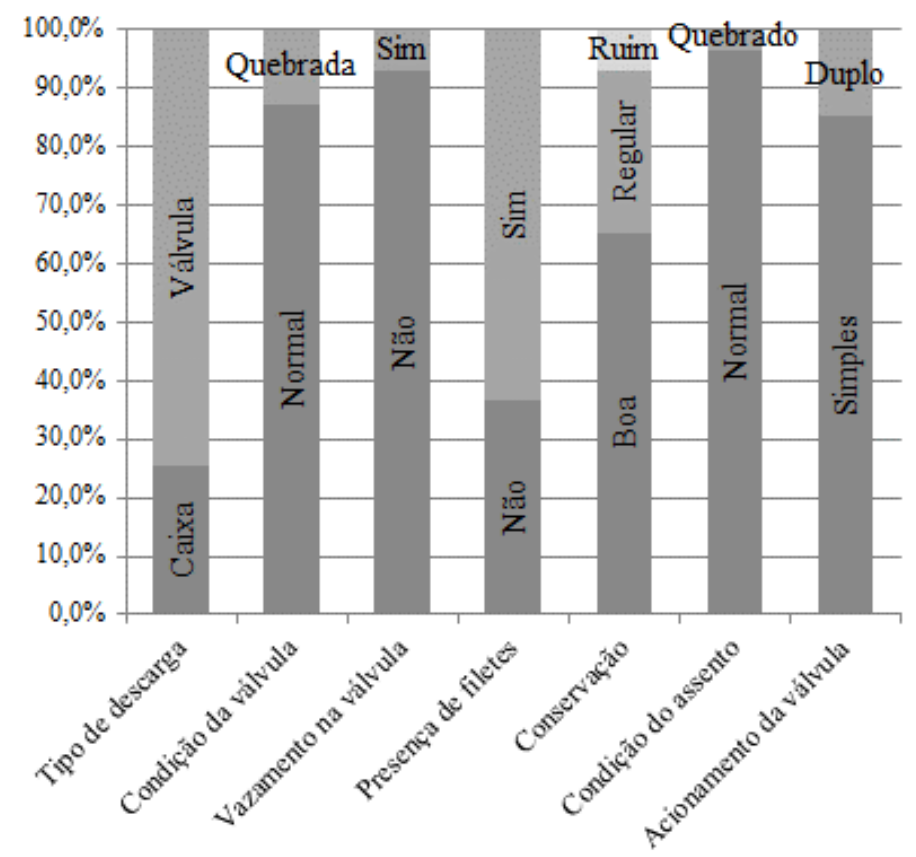

Figura 9 - Filetes das bacias sanitárias nos edifícios analisados

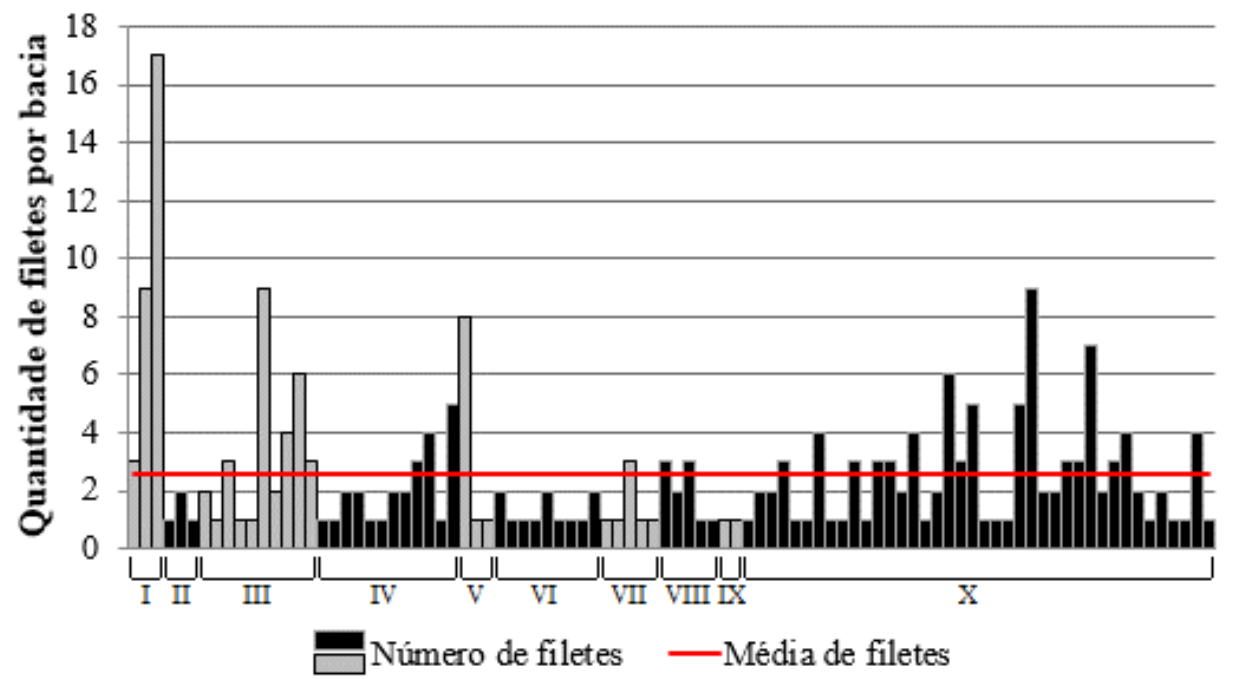


Figura 10 - Dados gerais dos mictórios nos edifícios analisados

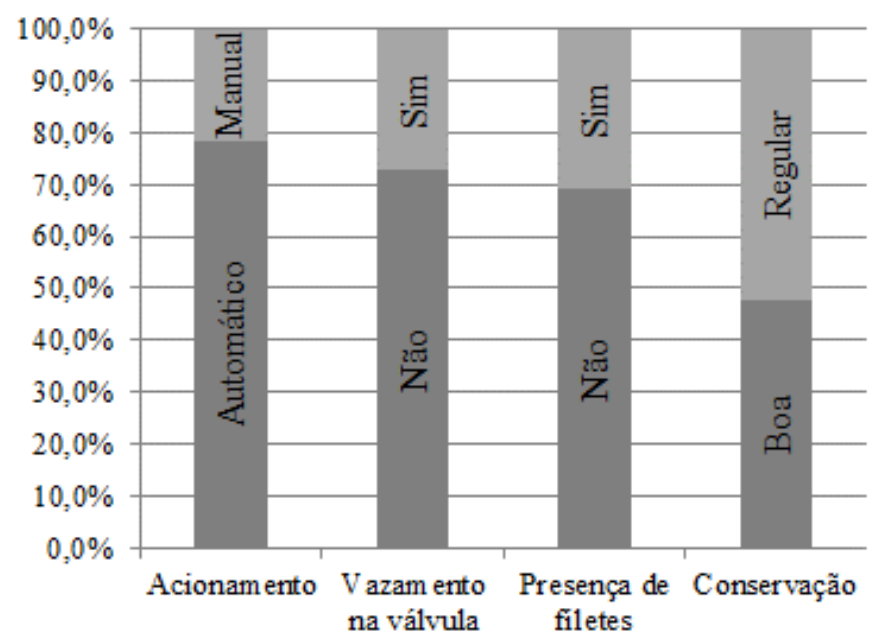

Figura 11 - Filetes dos mictórios nos edifícios analisados

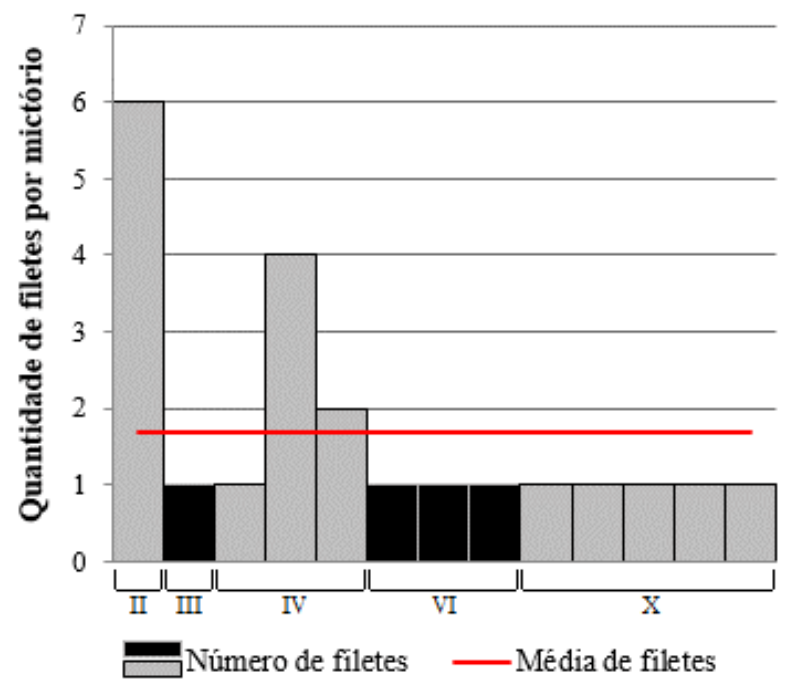

\section{Diagnóstico dos bebedouros}

Apesar de ter a função de servir aos usuários água potável, o bebedouro foi um equipamento hidrossanitário pouco encontrado nos dez edifícios. Somente um bebedouro estava interditado e não pôde ser medido. Foram analisados 25 bebedouros, presentes em nove edifícios.

\section{Dados gerais dos bebedouros}

A maioria dos bebedouros analisados apresentou em comum acionamento por botão $(72,0 \%)$ e jato específico somente para copo $(91,0 \%)$. Somente bebedouros de pressão apresentaram jato aberto ou disperso (12,0\%) e apenas um estava vazando sob a forma de gotejamento constante, como apresentado na Figura 12. O vazamento foi quantificado e a vazão obtida foi de $0,00058 \mathrm{~L} / \mathrm{s}$, o que equivale a uma estimativa de desperdício diário de 50,1 L/dia apenas para esse bebedouro. Quanto ao estado de conservação, 32,0\% apresentavam-se em condições regulares ou ruins.

Um dos bebedouros revelou péssimas condições de conservação, demonstrando, além de manchas, presença de ferrugem. O bebedouro encontrava-se em uso e poderia representar riscos à saúde dos funcionários, visto que a água também pode servir de veiculação para agentes biológicos e químicos.

\section{Vazão dos bebedouros}

A NBR 5626 (ABNT, 1998) também expõe a vazão de referência para bebedouros de $0,10 \mathrm{~L} / \mathrm{s}$, a qual é superior ao valor encontrado em todos os equipamentos com jato de copo, como ilustra a Figura 13. A vazão média encontrada foi de 0,03 L/s. 
Figura 12 - Dados gerais dos bebedouros nos edifícios analisados

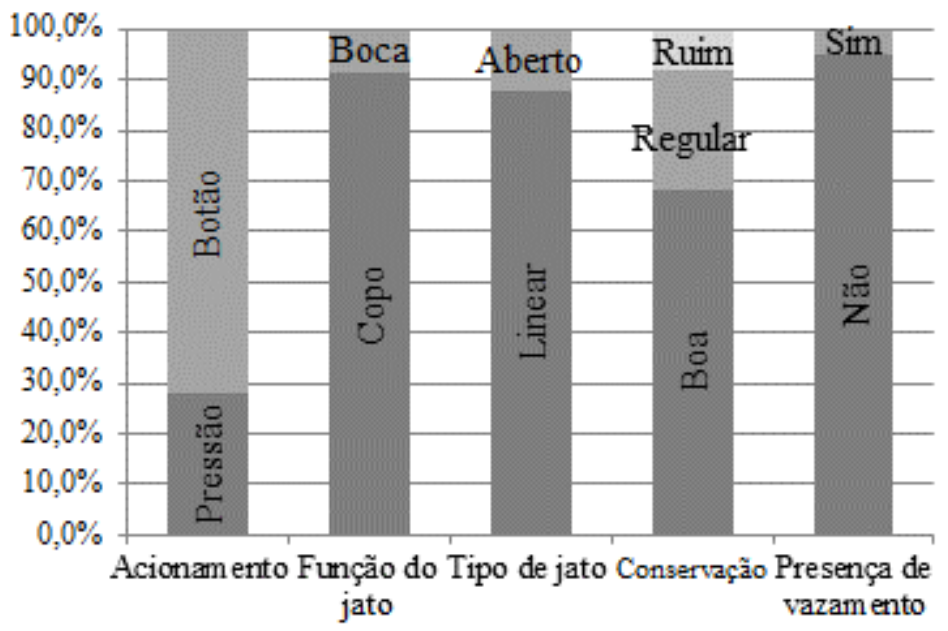

Figura 13 - Vazão dos bebedouros com jato de copo nos edifícios analisados

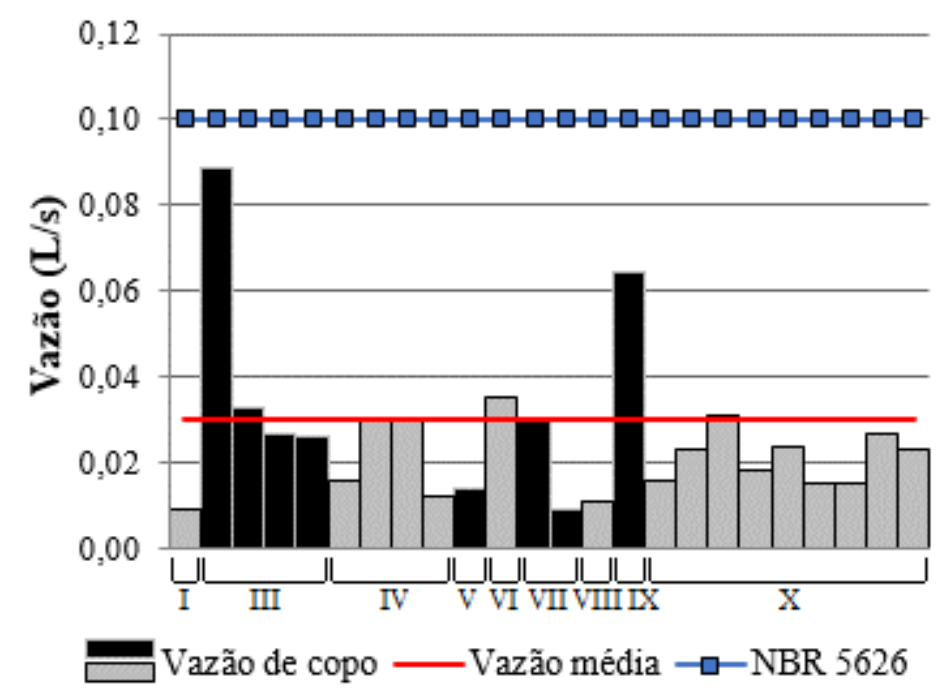

A Figura 14 mostra que, para bebedouros com jato de boca, a vazão também permaneceu abaixo do valor de referência em todas as medições, as quais também representam uma média de $0,03 \mathrm{~L} / \mathrm{s}$ para jatos com essa função.

\section{Diagnóstico dos chuveiros}

O chuveiro foi o equipamento hidrossanitário menos comum, presente em apenas três edificações, o que é justificável, visto que nos edifícios visitados são desempenhadas apenas funções administrativas. Foram analisados seis chuveiros.

\section{Dados gerais dos chuveiros}

Todos os chuveiros em que foram realizadas medições possuíam aquecimento por resistência elétrica. Quanto a vazamentos constantes, um chuveiro portava esse defeito na parte superior e outros dois na válvula, o que totaliza metade dos chuveiros com algum vazamento. Quanto à frequência de uso, funcionários relataram que um é frequentemente usado e outros quatro possuem algum uso periódico, mesmo que pequeno. Quanto à conservação, foi o equipamento que recebeu as avaliações mais baixas: 50,0\% foi classificado como regular e 50,0\% como em estado ruim de conservação, exibindo manchas escuras, muita concentração de poeira e fios desencapados. Ainda foi verificado um espesso vazamento por cima da peça de diafragma de alguns chuveiros, apresentando um possível risco de eletrocussão para qualquer usuário, eventualmente. Todos esses dados podem ser verificados na Figura 15. 
Figura 14 - Vazão dos bebedouros com jato de boca nos edifícios analisados

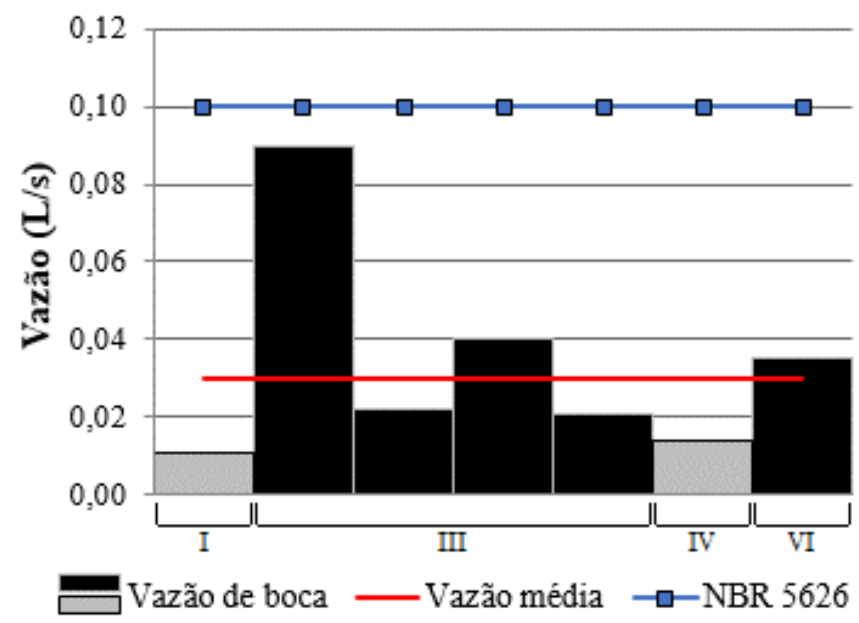

Figura 15 - Dados gerais dos chuveiros nos edifícios analisados

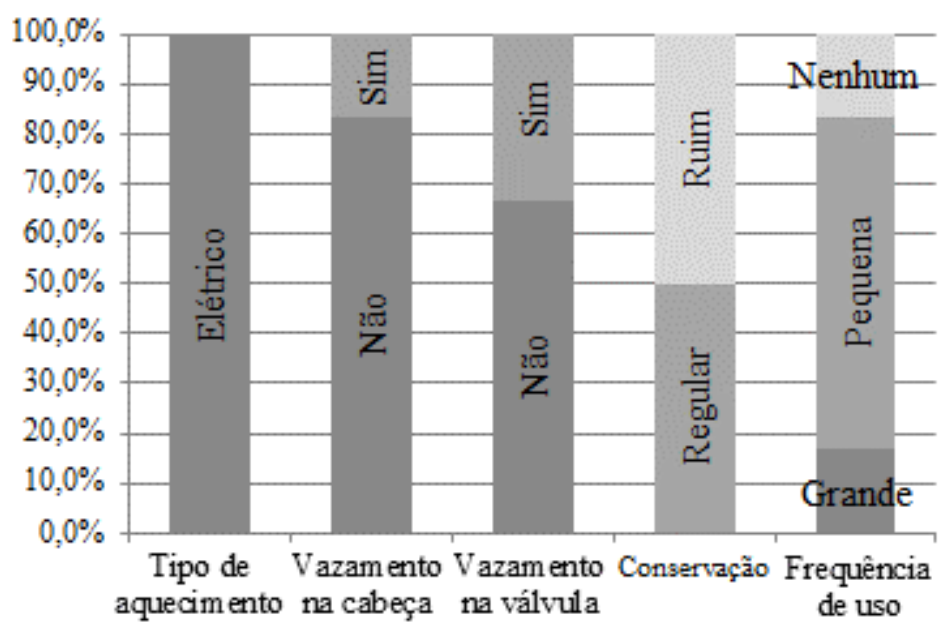

Outras avarias como válvulas emperradas e pontos de consumo sem o chuveiro instalado, que inviabilizaram a medição de vazão, também foram constatadas. Foi encontrado somente um chuveiro com gotejamento constante, que foi quantificado em 0,000064 L/s, equivalente a um possível desperdício diário de 5,5 L para esse chuveiro com defeito.

\section{Vazão dos chuveiros}

Apesar dessas patologias, todas as vazões estavam de acordo com a NBR 12483 (ABNT, 2015b), a qual estabelece que a vazão padrão de teste para que um chuveiro elétrico ligue sua resistência seja de pelo menos 3,0 L/min. Também pode ser verificado na Figura 16 que todas as vazões ficaram abaixo das certificações LEED (0,16 L/s) e AQUA $(0,20 \mathrm{~L} / \mathrm{s})$ e que $75,0 \%$ dos chuveiros operantes ficaram abaixo dos valores de referência da NBR 5626 (ABNT, 1998), que é 0,10 L/s para chuveiros elétricos. A média das vazões representa $0,09 \mathrm{~L} / \mathrm{s}$.

\section{Indicadores de consumo}

O consumo médio considerando os dez edifícios públicos ao longo de um ano foi de 39,6 litros/usuário/dia, de uma forma geral. Analisando os edifícios isoladamente, o menor indicador de consumo médio pertence ao Edifício X, com 16,6 litros/usuário/dia, coincidentemente o mesmo edifício em que foi constatado que todas as torneiras de lavatório, as quais são hidromecânicas e detentoras de arejador, operaram com vazão bastante baixa (média de 0,04 L/s). Em contrapartida, o Edifício V demonstrou ter a maior média de consumo, com 69,3 litros/usuário/dia.

Os indicadores de consumo referentes a cada mês ao longo de um ano de estudo, em litros/usuário/dia, das dez edificações podem ser verificados na Figura 17. É importante ressaltar

404 Kalbusch, A.; Gonçalves, F.; Cureau, R. J .; Defaveri, D.; Ramos, D. A. 
que os edifícios apresentam densidades muito diferentes não só de funcionários, mas também de pontos de consumo e áreas construídas bem diversificadas, quando pareados entre si. Por isso torna-se compreensível não só consumos significativamente diferentes como também dados bem diferenciados sobre os equipamentos hidrossanitários estudados. No caso do Edifício I o valor de IC apresenta um pico no sexto mês de análise, e isso possivelmente está relacionado a um grande vazamento que iniciou naquele mês e foi rapidamente consertado.

Os indicadores de consumo podem ser comparados com os valores apresentados por Kammers e Ghisi
(2006) para edifícios públicos na cidade de Florianópolis, SC. O indicador de consumo das edificações analisadas pelos autores variou de 18,3 a 67,2 litros/usuário/dia.

De uma forma mais ampla, os indicadores de consumo médios de cada um dos dez edifícios que fizeram parte dos estudos em campo, considerando um período histórico de 12 meses, podem ser conferidos na Figura 18. Como já mencionado anteriormente, o Edifício $\mathrm{V}$ apresentou o maior consumo médio, seguido pelos Edifícios I e IV, enquanto, por outro lado, os Edifícios VII, VIII e $\mathrm{X}$ demonstraram ter os consumos mais baixos.

Figura 16 - Vazão dos chuveiros nos edifícios analisados

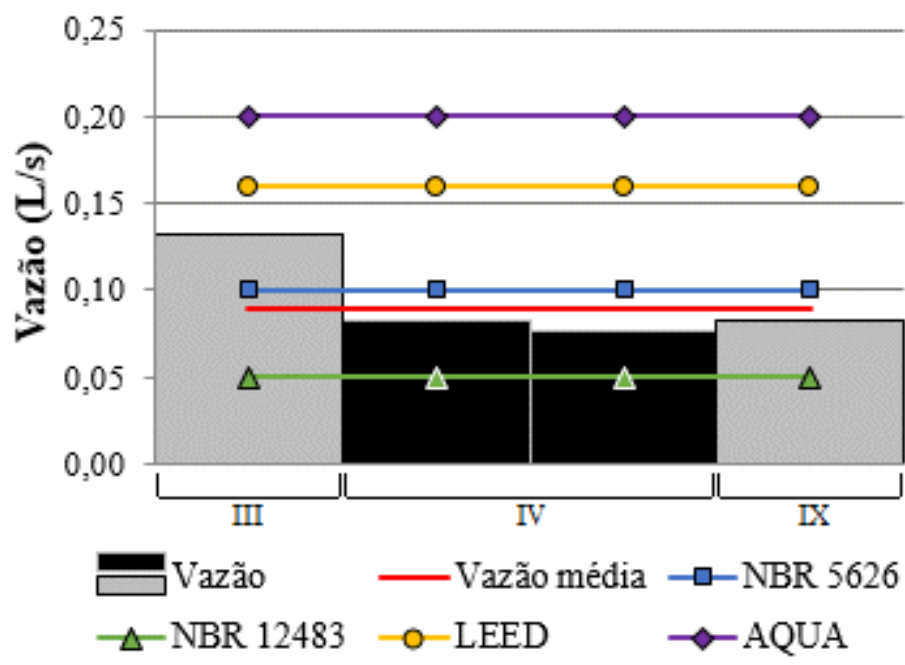

Figura 17 - Indicadores de consumo dos edifícios analisados

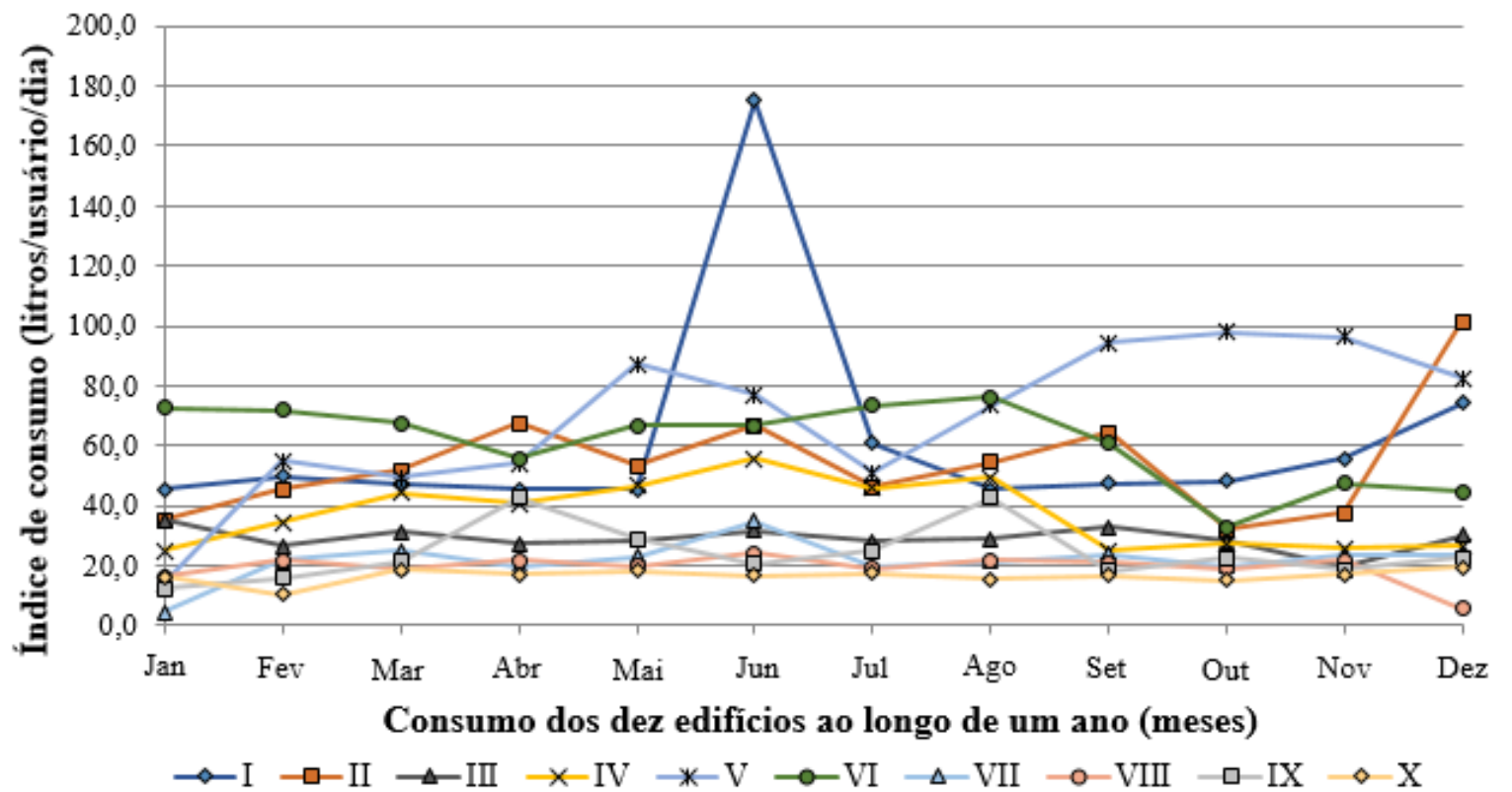


Figura 18 - Indicador de consumo médio de cada edifício

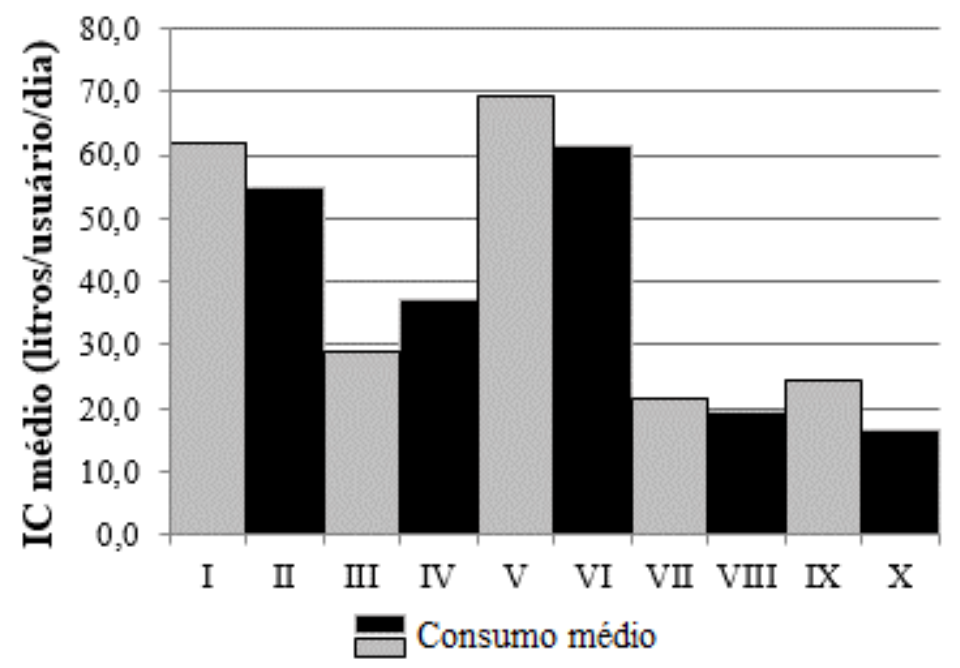

É importante salientar que o indicador de consumo de água das edificações pode ser maior ou menor em decorrência não apenas do desempenho dos equipamentos hidrossanitários instalados na edificação, mas também do nível de conscientização e dos hábitos dos usuários. Assim, além da necessidade de manutenção periódica dos equipamentos existentes, a especificação de equipamentos adequados à tipologia do edifício e a realização de campanhas para sensibilização dos usuários podem gerar economia de água.

\section{Considerações finais}

O principal objetivo deste artigo foi quantificar consumo, vazão e eventuais vazamentos, bem como qualificar as condições de operação e conservação dos equipamentos hidrossanitários de todos os pontos alimentados por sistemas de água fria nessas dez edificações em Joinville, SC.

A análise dos equipamentos hidrossanitários dos edifícios apresentou uma vasta quantidade de aparelhos em condições regulares ou ruins, o que pode indicar pouca ou total ausência de manutenção e consequente vínculo com perdas de água. Percebe-se ainda que, apesar de a maioria das torneiras, bacias sanitárias e mictórios instalados terem sido projetados visando à economia de água, muitos equipamentos apresentam avarias e há ocorrência de vazamentos em variadas magnitudes. Muitas vezes o usuário de edificações públicas percebe o vazamento em equipamentos hidrossanitários, porém não sabe a quem reportar tal falha. Nesses casos a comunicação torna-se uma ferramenta importante para promoção do uso racional da água.

Apesar do desenvolvimento de tecnologias que visam o consumo racional de água, os equipamentos hidrossanitários apresentam necessidade de manutenção periódica durante a vida útil. A manutenção deve fazer parte de um sistema de gestão do uso da água na edificação elaborado de maneira a identificar também outras necessidades inerentes a cada edifício e a seus usuários.

Para promoção do uso racional da água, além do uso de equipamentos economizadores citados neste artigo, podem ser realizadas também outras intervenções de ordem tecnológica, como o monitoramento do consumo de água nos sistemas prediais da edificação e a utilização de fontes alternativas de abastecimento.

Ações educacionais também podem ser consideradas de grande importância para a conscientização da população. A realização de campanhas para sensibilização dos usuários e a divulgação de informações relacionadas ao uso racional da água são importantes estratégias para gerar economia desse recurso.

Por fim, uma gestão adequada do uso da água, livre de excessos burocráticos, que induza os usuários a usarem a água de maneira mais eficiente e que respeite a imprescindibilidade da manutenção dos equipamentos hidrossanitários se mostra como a principal solução para os problemas descritos neste artigo.

Os resultados obtidos neste trabalho serviram de advertência para os edifícios abordados, visto que foram gerados relatórios contendo todos os dados encontrados durante as medições em cada edificação. Esses relatórios enumeram os problemas encontrados nos equipamentos hidrossanitários, identificados e locados em planta baixa. Isso permite que os responsáveis pela manutenção predial sejam capazes de reconhecer 
os pontos de consumo com suas respectivas inconveniências. Com isso, espera-se que as condições adversas observadas possam ser sanadas e que os usuários das edificações tenham conforto aliado à economia na utilização da água. Busca-se assim a sustentabilidade no uso da água, além de qualidade de vida melhorada no âmbito das edificações públicas administrativas.

\section{Referências}

ASSOCIAÇÃO BRASILEIRA DE NORMAS TÉCNICAS. NBR 10281: torneiras: requisitos e métodos de ensaio. Rio de Janeiro, 2015a.

\section{ASSOCIAÇÃO BRASILEIRA DE NORMAS} TÉCNICAS. NBR 12483: chuveiros elétricos. Rio de Janeiro, 2015b.

\section{ASSOCIAÇÃO BRASILEIRA DE NORMAS}

TÉCNICAS. NBR 13713: instalações hidráulicas prediais: aparelhos automáticos acionados mecanicamente e com ciclo de fechamento automático: requisitos e métodos de ensaio. Rio de Janeiro, 2009.

\section{ASSOCIAÇÃO BRASILEIRA DE NORMAS} TÉCNICAS. NBR 15097-1: aparelhos sanitários de material cerâmico: parte 1: requisitos e métodos de ensaios. Rio de Janeiro, 2011.

\section{ASSOCIAÇÃO BRASILEIRA DE NORMAS TÉCNICAS. NBR 5626: instalação predial de água fria. Rio de Janeiro, 1998.}

DEMANBORO, A. C. et al. Avaliação do Consumo de Água em Torneiras em Ambiente Universitário. Ambiente Construído, Porto Alegre, v. 15, n. 3, p. 135-143, jul./set. 2015.

GONÇALVES, O. M. et al. Execução e Manutenção de Sistemas Hidráulicos Prediais. São Paulo: Pini, 2000.

GONÇALVES, O. M. et al. Patologias dos Sistemas Prediais de Água Fria em escolas municipais de Campinas, São Paulo. In: CONGRESO LATINOAMERICANO DE PATOLOGÍA DE LA CONSTRUCCIÓN, 8.CONGRESO DE LA CALIDAD DE LA CONSTRUCCIÓN, 10., Asunción, 2005, Asunción. Anais... Asunción: Conpat, 2005.
ILHA, M. S. de O.; GONÇALVES, O. M.; OLIVEIRA JÚNIOR, O. B. de. Avaliação do Desempenho de Bacias Sanitárias de Volume de Descarga Reduzido Quanto à Remoção e Transporte de Sólidos. Ambiente Construído, Porto Alegre, v. 2, n. 4, p. 47-61, out./dez. 2002.

KAMMERS, P. C.; GHISI, E. Usos Finais de Água em Edifícios Públicos Localizados em Florianópolis, SC. Ambiente Construído, Porto Alegre, v. 6, n. 1, p. 75-90, jan./mar. 2006.

MARINHO, E. C. A. Uso Racional da Água em Edificações Públicas. Belo Horizonte, 2007. 72 f. Monografia (Especialização em Construção Civil) - Universidade Federal de Minas Gerais, Belo Horizonte, 2007.

NUNES, S. S. Estudo da Conservação de Água em Edifícios Localizados no Campus da Universidade Estadual de Campinas. Campinas, 2000. 145 f. Dissertação (Mestrado em Engenharia Civil) - Escola de Engenharia, Universidade Estadual de Campinas, Campinas, 2000.

OLIVEIRA, L. H. de. As Bacias Sanitárias e as Perdas de Água nos Edifícios. Ambiente Construído, Porto Alegre, v. 2, n. 4, p. 39-45, out./dez. 2002.

OLIVEIRA, L. H.; GONÇALVES, O. M. Metodologia Para Implantação de Um Programa de Uso Racional de Água em Edifícios. São Paulo, 1999. 18 f. Tese (Doutorado em Engenharia Civil) - Universidade de São Paulo, São Paulo, 1999.

PROENÇA, L. C.; GHISI, E. Water End-Uses in Brazilian Office Buildings. Resources,

Conservation and Recycling, v. 54, n. 8, p. 489500, jun. 2010.

\section{Agradecimentos}

Os autores agradecem à Fundação de Amparo à Pesquisa e Inovação do Estado de Santa Catarina (FAPESC) pelo apoio recebido. 


\section{Andreza Kalbusch}

Laboratório de Sistemas Prediais, Departamento de Engenharia Civil | Universidade do Estado de Santa Catarina | Rua Paulo Malschitzki, 200 | J oinville - SC - Brasil | CEP 89219-710| Tel.: (47) 3481-7807 | E-mail: andreza.kalbusch@udesc.br

\section{Felipe Gonçalves}

Departamento de Engenharia Civil | Universidade do Estado de Santa Catarina | Tel.: (47) 3481-7936| E-mail: felipehipos@hotmail.com

\section{Roberta J acoby Cureau}

Departamento de Engenharia Civil | Universidade do Estado de Santa Catarina | E-mail: robertacureau@hotmail.com

\section{Daiele Defaveri}

Departamento de Engenharia Civil | Universidade do Estado de Santa Catarina | E-mail: daieledef@gmail.com

\section{Doalcey Antunes Ramos}

Departamento de Engenharia Civil | Universidade do Estado de Santa Catarina | Tel.: (47) 3481-7936 | E-mail: doalcey.ramos@udesc.br

\section{Revista Ambiente Construído}

Associação Nacional de Tecnologia do Ambiente Construído

Av. Osvaldo Aranha, 99 - 30 andar, Centro

Porto Alegre - RS - Brasil

$$
\text { CEP 90035-190 }
$$

Telefone: +55 (51) 3308-4084

Fax: +55 (51) 3308-4054

www. seer. ufrgs. br/ ambienteconstruido

E-mail: ambienteconstruido@ufrgs.br

408 Kalbusch, A.; Gonçalves, F.; Cureau, R. J.; Defaveri, D.; Ramos, D. A. 